\title{
Creating Purchase Intention Throughs Positive Electronic Wom, Brand Attitude, Satisfaction, and Brand Awareness. Case of Wardah Exclusive Lip Cream on Instagram
}

\author{
Vita Briliana ${ }^{1}$, Nathasya Esterita Juli Silaen ${ }^{2}$ \\ Trisakti School of Management, Jakarta, Indonesia ${ }^{1,2}$ \\ vita@stietrisakti.ac.id ${ }^{1}$
}

\begin{abstract}
This study was designed to determine the impact of positive E-WOM, brand attitude, satisfaction, and brand awareness towards purchase intention of Wardah Exclusive Lip Cream. Purposive sampling is used by comprising questionnaire of 124 respondents that are @wardahbeauty Instagram's followers. Data analyzed using Structural Equation Modeling (SEM) using SmartPLS 3.0. The impact of Positive E-WOM to Brand Attitude, Satisfaction, and Brand Awareness is significant, positive and supported. Positive E-WOM, Brand Attitude, Satisfaction, and Brand Awareness to Purchase Intention has significant, positive and supported impact. Brand Awareness has no significant impacts, positive impact but not supported to Satisfaction.
\end{abstract}

Keywords: Brand Attitude; Brand Awareness; Wardah.

\section{Introduction}

The growing popularity of social broadcasting networks such as Facebook and Twitter have transformed the way online word of mouth (WOM) is disseminated and consumed in the digital age [1]. According to Dodson (2016:367), social media is a catchall term used to describe the tools and technologies that facilitate social interaction over the internet. Based on an online news report released by Association of Internet Service Provider Indonesia [2], Indonesia was reported to have more than 143.26 million internet users in 2017, and about $87.13 \%$ have social media accounts. A personal experience, family and friends, media, the internet, and increasingly social media strongly affect the attitude [3]. There are several ways to create a positive word-of-mouth, such as using brand endorsers, brand spokespersons, celebrities, and key opinion leadership [3]. This change of marketing, especially in digital media, affected the consumers purchase behavior, from recognizing the needs until postpurchase behavior. The example of industry that try to fit in and develop their market size are cosmetic and skin care industries. Within a year, Indonesia's cosmetic industry had recorded new fantastic achievement. The industry has grown $20 \%$ than 2016, four times than national economic growth rate. Wardah Cosmetics produced by PT Paragon Technology and Innovation (PTI), started it journey on 1995, introduce itself as the first Halal cosmetic in Indonesia. Wardah Cosmetics already got verified bandage from Instagram and highest follower number (over than 1.5 million followers) compared to the competitor. We will 
evaluate the digital marketing strategy of Wardah Exclusive Lip Cream, since its existence on Instagram was over than 63,000 photos shared by the Instagram users.

\section{Literature Review}

\subsection{Positive Electronic Word-of-Mouth}

Word-of-mouth communication is a communication process of recommending either individually or collectively towards a product or service in order to give in information personally [4]. Social media is one of example of online word-of-mouth. In Schiffman and Wisenblit (2015, p281), word-of-mouth refers to informal conversations between friends concerning products or services. It consists of communication where satisfied customers tell other people how much they like a business, product, service, or event (although the information transmitted can also be negative). Word-of-mouth refers to all kinds of interpersonal communication (positive and negative) about company, brand, or product between a receiver and a communicator, who is perceived as non-commercial [5]. In terms of social media or electronic word-of-mouth, [6] defined Electronic word-of-mouth as any positive or negative statement made by a potential, actual, or former customer about a product or a company, available to a multitude of people and institutions via the internet. [3] define electronic word-of-mouth as "word-of-mouth taking place online and occurs in social networks, brand communities, blogs, chat rooms, and tweets". To create an electronic wordof-mouth, someone should connect to an internet and using a specific platform.

\section{H1: Positive E-WOM has significant impact on Brand Attitude}

H2: Positive E-WOM has significant impact on Satisfaction

H3: Positive E-WOM has significant impact on Brand Awareness

H4: Positive E-WOM has significant impact on Purchase Intention

\subsection{Brand Awareness}

A brand must be known and remembered by the consumer to lead the market. Brand awareness can be a brand successfulness predictor [7]. A brand that easily recognized by its consumer may determine if consumer next purchase decision. They can be loyal to a brand, or decided to switch to another. According to [4], brand awareness is the ability of consumer to recognize or recall the brand in sufficient detail to make a purchase. [8] said that "brand awareness is the probability of a consumer's familiarity with the given brand"; more familiar consumer with the brand, the easily brand remembered by consumer. Brand attitude cannot be form and a purchase desire will not occur if the consumer does not know the brand. [9] stated that brand awareness is related to the strength of the resulting brand node or trace in memory, as reflected by consumers' ability to identify the brand under different conditions.

\section{H5: Brand Awareness has significant impact on Satisfaction H6: Brand Awareness has significant impact on Purchase Intention}

\subsection{Brand Attitude}

According to [4], brand attitude refers to consumer evaluation of the brand's perceived ability to meet a currently relevant need. A marketer should help the consumer to evaluate the brand perceived ability to meet currently relevant need. Relevant brand needs may be negatively oriented (problem removal, problem avoidance, incomplete satisfaction, normal depletion) or positively oriented (sensory gratification, intellectual stimulation, or social approval). Based on [3], an attitude is a learned predisposition to behave in a consistently favorable or unfavorable way toward a given object. In the context of consumer behavior, an 'object' can be a product, brand, service, price, package, advertisement, promotional medium, 
or the retailer selling product, among many other aspects of consumption. Based on a journal by Olson and Mitchell (2000), brand attitude defined as "consumer's overall evaluation of a brand. Attitude is stable and enduring predispositions to behave". Similar with other experts, a journal by [10] said that brand attitude is an assessment around favorable and unfavorable responses to brand-related stimuli or conviction.

\section{H7: Brand Attitude has a significant impact on Satisfaction}

\section{H8: Brand Attitude has a significant impact on Purchase Intention}

\subsection{Satisfaction}

Based on [4] customer satisfaction is a person's feelings of pleasure or disappointment that result from comparing a product or service performance (or outcome) to expectations. When the consumer satisfied with a product/service, they will express their feelings and may recommend the product or service to other relatives. [11] also stated that satisfaction as an attitude-like judgment following a consumption experience. Satisfaction toward a product or service will be examined after they consume the product. The main thing that influences the consumer satisfaction is their expectation before consuming a product or purchasing a service. [3] stated that satisfaction refers to costumers' perception of the performance of the product or service in relation to their expectation.

\section{H9: Satisfaction has significant impact on Purchase Intention}

\subsection{Purchase Intention}

[12] defined purchase intention as "another set of possible measures closely related to brand attitudes and consideration. Purchase intention examines consumer's lean to purchase a product or brand or switch to another brand or product. According to the statement from Engel, Kollat, and Blackwell cited by [13] purchase intention is "a process used to evaluate consumer decision making". This explained if purchase intention is a process so it has stages in evaluating the purchase decision that will be taken by an individual.

[14] defined purchase intention as "a decision based on consumer attitude toward buying a brand". They indicated that the decision decided by the consumer to make a purchase is based on the attitude toward the product offered.

\section{Method}

Structural Equation Method (SEM) that simultaneously analyze multiple variables representing measurements associated with individuals, companies, events, activities, situations, and so forth. Goal of PLS-SEM is to measure the characteristic of constructs in model relationship (latent variables). Moreover PLS-SEM can better handle formative measurement models (validity assessment, significance and relevance of indicator weights, and indicator collinearity) and has advantages when sample size is relatively small. This research using 124 valid respondents from 175 distributed questionnaires to the followers of @ wardahbeauty on Instagram through the direct message features. The valid respondent must have a criteria: [1] a follower of @ wardahbeauty, [2] has an active instagram account for one past month, [3] woman and 17 years old minimum, [4] ever purchase Wardah Cosmetic Products, and [5] never purchase Wardah Exclusive Lip Cream. In this research, the quantitative method was used by the researcher to obtain the primary data.

\section{Result}

Based on data gathering process, the result is consisting of characteristics from respondent's participation as Table 1 shown below: 
Table 1. Respondent Characteristics

\begin{tabular}{|l|l|l|}
\hline Definition & & Total \\
\hline Gender & Female & 124 \\
\hline Respondent's Ages & $17-19$ & 31 \\
\hline \multirow{5}{*}{ Respondent's Occupation } & $20-22$ & 32 \\
\hline \multirow{3}{*}{} & $23-25$ & 29 \\
\hline & $26-28$ & 22 \\
\hline & $>28$ & 10 \\
\hline Followers of @ WardahBeauty on Instagram & Student/College Student & 72 \\
\cline { 2 - 3 } & Employee & 30 \\
\cline { 2 - 3 } & Part-timer & 8 \\
\cline { 2 - 3 } & Freelancer & 4 \\
\cline { 2 - 3 } & Work and Study & 10 \\
\hline $\begin{array}{l}\text { Ever Purchase Wardah Product Except Wardah } \\
\text { Exclusive Lip Cream }\end{array}$ & Yes & 124 \\
\hline Ever Purchase Wardah Exclusive Lip Cream & Yes & 124 \\
\hline
\end{tabular}

(Source: Primary data processed (2018))

According to Hair et.al (2017:115) discriminant validity is the extent to which a construct is distinct from other others empirical standards. Moreover, the cross loading specifically is an indicator's outer loading on the associated construct $s$ that should be greater than any of its cross-loadings on other constructs.

Table 2. Cross Loading for Discriminant Validity Test

\begin{tabular}{|c|c|c|c|c|c|}
\hline Indicator & PE & BT & SA & BW & PI \\
\hline PE1 & $\mathbf{0 . 8 0 6}$ & 0.278 & 0.358 & 0.166 & 0.173 \\
\hline PE2 & $\mathbf{0 . 8 7 2}$ & 0.390 & 0.370 & 0.195 & 0.228 \\
\hline PE3 & $\mathbf{0 . 9 1 2}$ & 0.463 & 0.429 & 0.349 & 0.331 \\
\hline PE4 & $\mathbf{0 . 9 3 3}$ & 0.527 & 0.562 & 0.323 & 0.418 \\
\hline BT1 & 0.458 & $\mathbf{0 . 8 4 7}$ & 0.648 & 0.450 & 0.648 \\
\hline BT2 & 0.414 & $\mathbf{0 . 8 5 4}$ & 0.691 & 0.437 & 0.682 \\
\hline BT3 & 0.374 & $\mathbf{0 . 8 7 3}$ & 0.658 & 0.574 & 0.834 \\
\hline BT4 & 0.435 & $\mathbf{0 . 8 6 3}$ & 0.694 & 0.406 & 0.690 \\
\hline SA1 & 0.406 & 0.802 & $\mathbf{0 . 8 5 3}$ & 0.394 & 0.781 \\
\hline
\end{tabular}




\begin{tabular}{|c|l|l|l|l|l|}
\hline SA2 & 0.476 & 0.654 & $\mathbf{0 . 8 9 9}$ & 0.394 & 0.598 \\
\hline SA3 & 0.375 & 0.389 & $\mathbf{0 . 7 4 3}$ & 0.273 & 0.345 \\
\hline BW1 & 0.188 & 0.486 & 0.342 & $\mathbf{0 . 8 5 7}$ & 0.592 \\
\hline BW2 & 0.034 & 0.255 & 0.073 & $\mathbf{0 . 7 0 5}$ & 0.364 \\
\hline BW3 & 0.392 & 0.491 & 0.482 & $\mathbf{0 . 8 5 0}$ & 0.605 \\
\hline PI1 & 0.334 & 0.764 & 0.728 & 0.531 & $\mathbf{0 . 9 3 4}$ \\
\hline PI2 & 0.439 & 0.757 & 0.641 & 0.655 & $\mathbf{0 . 8 1 2}$ \\
\hline PI3 & 0.309 & 0.756 & 0.754 & 0.533 & $\mathbf{0 . 9 1 1}$ \\
\hline PI4 & 0.136 & 0.580 & 0.464 & 0.674 & $\mathbf{0 . 8 1 4}$ \\
\hline PI5 & 0.256 & 0.725 & 0.571 & 0.546 & $\mathbf{0 . 8 4 1}$ \\
\hline
\end{tabular}

(Source: Primary data processed using SEMPLS 3.0 (2018))

Table 3. Convergent Validity And Composite Reliability

\begin{tabular}{|c|c|c|c|c|c|}
\hline Variable & Items & Loading & AVE & $\begin{array}{l}\text { Composite } \\
\text { Reliability }\end{array}$ & $\begin{array}{c}\text { Cronbach' } \\
\text { Alpha }\end{array}$ \\
\hline \multirow{4}{*}{ Positive WOM } & PE1 & 0.806 & \multirow{4}{*}{0.778} & \multirow{4}{*}{0.933} & \multirow{4}{*}{0.906} \\
\hline & PE2 & 0.872 & & & \\
\hline & PE3 & 0.912 & & & \\
\hline & PE4 & 0.933 & & & \\
\hline \multirow{4}{*}{ Brand Attitude } & BT1 & 0.847 & \multirow{4}{*}{0.738} & \multirow{4}{*}{0.919} & \multirow{4}{*}{0.882} \\
\hline & BT2 & 0.854 & & & \\
\hline & BT3 & 0.873 & & & \\
\hline & BT4 & 0.863 & & & \\
\hline \multirow{3}{*}{ Satisfaction } & SA1 & 0.853 & \multirow{3}{*}{0.696} & \multirow{3}{*}{0.872} & \multirow{3}{*}{0.793} \\
\hline & SA2 & 0.899 & & & \\
\hline & SA3 & 0.743 & & & \\
\hline \multirow{3}{*}{$\begin{array}{c}\text { Brand } \\
\text { Awareness }\end{array}$} & BW1 & 0.857 & \multirow{3}{*}{0.638} & \multirow{3}{*}{0.839} & \multirow{3}{*}{0.736} \\
\hline & BW2 & 0.705 & & & \\
\hline & BW3 & 0.850 & & & \\
\hline \multirow{5}{*}{$\begin{array}{l}\text { Purchase } \\
\text { Intention }\end{array}$} & PI1 & 0.934 & \multirow{5}{*}{0.746} & \multirow{5}{*}{0.936} & \multirow{5}{*}{0.914} \\
\hline & PI2 & 0.812 & & & \\
\hline & PI3 & 0.911 & & & \\
\hline & PI4 & 0.814 & & & \\
\hline & PI5 & 0.841 & & & \\
\hline
\end{tabular}

(Source: Primary data processed using SEMPLS 3.0 (2018))

A common rule of thumb is that the standardized outer loadings should be 0.708 or higher. This means that an indicator's outer loading should be above 0.708 since that number squared (0.7082) equals to 0.50 ( 50 per cent). Note that in most instances, 0.70 is considered close to 0.708 to be acceptable. [15]. Using the same logic that used with cross loading analysis, an AVE value should be 0.50 (50 per cent) or higher to indicate that. On average, the construct explains more than half of the variance of its indicators. [15]. 
Table 4. $\mathrm{R}^{2}$ Value

\begin{tabular}{|c|c|}
\hline Variable & R Square \\
\hline Brand Attitude & 0.638 \\
\hline Satisfaction & 0.632 \\
\hline Brand Awareness & 0.795 \\
\hline Purchase Intention & 0.796 \\
\hline
\end{tabular}

Source: Primary data processed (2018)

For example, in this research brand Image has 0.763 R-Square value, which means 76.3per cent brand image validity construct can be described by perceived value variable, and the remaining 33.7 per cent will be described by other factors outside the model, and so with other variables described above.

Table 5. Predictive Relevance $\mathrm{Q}^{2}$ Value Test

\begin{tabular}{|c|c|}
\hline Variables & $\mathbf{Q}^{\mathbf{2}}(\mathbf{= 1 - S S E} / \mathbf{S S O})$ \\
\hline Brand Attitude & 0.163 \\
\hline Satisfaction & 0.386 \\
\hline Brand Awareness & 0.040 \\
\hline Purchase Intention & 0.550 \\
\hline
\end{tabular}

Source: Primary data processed (2018)

As a rule of thumb, the values can be respectively described as small (0.02), medium (0.15), and large (0.35) [15]. Based on the Table 5, Brand Awareness has a small effect size, followed by Brand Attitude with medium effect size with Q2 value is 0.163 . Satisfaction and Purchase Intention have a large effect size because their value is more than 0.35 .

When the size of the resulting empirical t value is above 1.96, we can assume that the path coefficient is significantly different from zero at a significance level of 5 per cent $(\alpha=0.05$; two tailed test). [15].

Table 6. Summary of The Structural Model

\begin{tabular}{|c|l|c|c|c|c|c|}
\hline $\begin{array}{c}\text { Hypoth } \\
\text { eses }\end{array}$ & Path & $\begin{array}{c}\text { Original } \\
\text { Sample (O) }\end{array}$ & $\begin{array}{c}\text { Standard } \\
\text { Deviation } \\
\text { (STDEV) }\end{array}$ & $\begin{array}{c}\text { T Statistics } \\
(\mid \mathbf{O} / \text { STDEV|) }\end{array}$ & $\begin{array}{c}\text { P } \\
\text { Values }\end{array}$ & Supported \\
\hline $\mathrm{H}_{1}$ & PE $\rightarrow$ BW & 0.308 & 0.089 & 3.461 & 0.001 & Yes \\
\hline $\mathrm{H}_{2}$ & PE $\rightarrow$ BT & 0.488 & 0.075 & 6.543 & 0.000 & Yes \\
\hline $\mathrm{H}_{3}$ & PE $\rightarrow$ SA & 0.157 & 0.072 & 2.172 & 0.030 & Yes \\
\hline $\mathrm{H}_{4}$ & PE $\rightarrow$ PI & -0.136 & 0.057 & 2.395 & 0.017 & Yes \\
\hline $\mathrm{H}_{5}$ & BW $\rightarrow$ SA & 0.004 & 0.064 & 0.056 & 0.955 & No \\
\hline $\mathrm{H}_{6}$ & BW $\rightarrow$ PI & 0.324 & 0.054 & 6.041 & 0.000 & Yes \\
\hline $\mathrm{H}_{7}$ & BT $\rightarrow$ SA & 0.704 & 0.054 & 13.096 & 0.000 & Yes \\
\hline
\end{tabular}




\begin{tabular}{|c|l|l|l|l|l|l|}
\hline $\mathrm{H}_{8}$ & BT $\rightarrow$ PI & 0.523 & 0.075 & 7.015 & 0.000 & Yes \\
\hline $\mathrm{H}_{9}$ & $\mathrm{SA} \rightarrow \mathrm{PI}$ & 0.255 & 0.072 & 3.552 & 0.000 & Yes \\
\hline
\end{tabular}

Source: Data Processing on SmartPLS 3.0

The trade business (T2), the telephone has been used to find buyers and/or sell land, agricultural and plantation products, and to sell superior products. This benefit is not optimal because the prospective buyers contacted are limited to those who are known. The market for superior products is "closed" or not yet known by the wider community, such as superior products in the form of handicrafts from the Baduy tribe. For residents who have received chat services such as WhatsApp application, it is also limited to people they know or to those who have visited Kanekes Village as a place of residence for the Baduy Tribe. User and telephone relations cannot invite buyers from outside the Lebak area. The availability of telephones is limited to relations with those who are known only, so it is impossible to inform various superior products of the village market. Constraints occur in promoting superior products, so they cannot attract buyers who are in urban areas or outside the Lebak area.

\section{Discussion and Conclusion}

From Table 6, we can measure the significance impact of each variables based on one-goal (causational) impact in research model. We can analyze each hypothesis which has been stated in the beginning of research process.

a. Positive Electronic Word-of-Mouth has a significant impact on Brand Awareness (H1), with t Test score $3.461>1.96$. The original sample is 0.308 which mean the impact of Positive Electronic Word-of-Mouth on Brand Awareness is positive.

b. Positive Electronic Word-of-Mouth has a significant impact on Brand Attitude (H2), with t Test score $6.543>1.96$. The original sample is 0.075 which mean the impact of Positive Electronic Word-of-Mouth on Brand Attitude is positive.

c. Positive Electronic Word-of-Mouth has a significant impact on Satisfaction (H3), with t Test score $2.172<1.96$. The original sample is 0.072 which mean the impact of Positive Electronic Word-of-Mouth on Satisfaction is positive.

d. Positive Electronic Word-of-Mouth has a significant impact on Purchase Intention (H4), with t Test score $2.395>1.96$. The original sample result is -0.136 which mean the impact of Positive Electronic Word-of-Mouth on Purchase Intention is negative.

e. Brand Awareness has no significant impact on Satisfaction (H5), with t Test score $0.056<$ 1.96. The original sample is 0.004 which mean the impact of Brand Awareness on Satisfaction is positive.

f. Brand Awareness has a significant impact on Purchase Intention (H6), with t Test score $6.041>1.96$. The original sample is 0.324 which mean the impact of Brand Awareness on Purchase Intention is positive.

g. Brand Attitude has a significant impact on Satisfaction (H7), with t Test score $13.096>$ 1.96. The original sample is 0.704 which mean the impact of Brand Attitude on Satisfaction is positive.

h. Brand Attitude has a significant impact on Purchase Intention (H8), with t Test score 7.015 $>1.96$. The original sample is 0.523 which mean the impact of Brand Attitude on Purchase Intention is positive.

i. Satisfaction has a significant impact on Purchase Intention (H9), with t Test score 3.552 > 1.96. The original sample is 0.255 which mean the impact of Satisfaction on Purchase Intention is positive. 


\subsection{Implication}

As we can see from the data processing result, the variable that impacts the most to the purchase intention is brand attitude. It does mean the company should focus on creating, delivering, campaigning, and massiving the desired attitude to make the potential customer has an intention to purchase the product. The result that positive e-wom does bring a negatiive impact to the purchase intention reflects that the message on the e-wom (especially amplified WOM that created by the company) must have a balance information, both positiveness and negativeness, of the product, so they will had a satisfaction because their expectation not too high because the messages are full of goodness of the product. The company can design their marketing communication to create the new attitude or trend to increase the product purchase intention. Positive e-WoM as the main variable on this research has a significant role in determining the brand attitude, brand awareness, satisfaction, and also the purchase Intention of Wardah Exclusive Matte Lip Cream. The brand should design the message acceptable and make sense during deliver the advantage of the product. Wardah can establish a campaign of using lipcream in any occasions, the look, and also collaborated with many influencers to build the attitude.

\section{References}

[1] H. Rui, Y. Liu, Whinston, and A., "Whose and what chatter matters? The effect of tweets on movie sales," Decis. Support Syst. Vol, vol. 55, no. 4, pp. 863-870.

[2] "Association of Internet Service Provider Indonesia (APJII). 2017. Penetration and Internet User," in Behavior in Indonesia, .

[3] L. G. Schiffman and J. L.Wisenbilt, Consumer Behavior, 11thed ed. Pearson Global Edition: United States.

[4] P. Kotler and K. L.Keller, "No Title," Mark. Manag., vol. 15.

[5] J. Arndt, S. Solomon, T. Kasser, and and Kennon M. Sheldon, "The Urge to Splurge: A Terror Management Theory Account of Materialism and Consumer Behavior," $J$. Consum. Psychol., vol. 14, no. 3, pp. 198-212.

[6] T. Henning-Thurau, K. P. Gwinner, G. Walsh, Gremler, and D.D., "Electronic wordof-mouth via customer opinion platform: what motivates consumers to articulate themselves on the internet," J. Interact. Mark., vol. 18, no. 1, pp. 38-52.

[7] Y. HS, “"Analysis Of Impact Unconventional Tin Mining To Flood (Studies In Pangkalpinang City The Province Of Bangka Belitung 2016),' Jurnal Prodi Manajemen Bencana Universitas Pertahanan Program Studi Manajemen Bencana," in Untuk Keamanan Nasional, vol. III, vol. 1, pp. 1-17.

[8] J. R. Rossiter, L. Percy, Donovan, and R.J., “A better advertising planning grid,” J. Advert. Res., vol. 31, pp. 5-11.

[9] K. L. Keller, "Strategic Brand Management: Building, Measuring, and Managing Brand Equity, Pearson Education,Upper Saddle.” River, NJ.

[10] M. Murphy, "Habermas and Social Research: Between Theory and Method," in London:ROUTLEDGE ADVANCES IN SOCIOLOGY,

[11] C. Lovelock and J. Wirtz, Services Marketing, 7th ed. Pearson: New Jersey.

[12] D. A. Aaker, Keller, and K. L, "Consumer evaluations of brand extensions," J. Mark., pp. 27-41.

[13] L. Y. Lin, Chen, and Y. W, "A study on the influence of purchase intentions on repurchase decisions: the moderating effects of reference groups and perceived risk," Tour. Rev., vol. 64, pp. 3-28.

[14] J. C. Olson, Mitchell, and A. A, "Are product attribute beliefs the only mediator of 
advertising effects on brand attitude?," Advert. Soc. Rev., vol. 1, no. 1.

[15] A Primer on Partial Least Squares Structural Equation Modeling, PLS-SEM). 2nd ed. Sage: United States. 